\title{
Pengaruh Tepung Daun Lemna (Lemna minor) Fermentasi pada Pakan Formulasi terhadap Pertumbuhan Ikan Gurame (Osphronemus gouramy)
}

\section{Effect of Fermented Lemna minor Leaf Meal in Diet for Growth Giant Gouramy (Osphronemus gouramy)}

\author{
Slamat Harianto Sukran ${ }^{1 *}$, Indra Suharman ${ }^{1}$, Adelina ${ }^{1}$ \\ ${ }^{1}$ Jurusan Budidaya Perairan, Fakultas Perikanan dan Kelautan Universitas Riau \\ email:slamatharianto9@gmail.com
}

(Received: 01 Mei 2021; Accepted: 30 Juni 2021)

\begin{abstract}
ABSTRAK
Penelitian ini dilaksanakan pada bulan Desember 2016 s/d Februari 2017. Penelitian ini bertujuan untuk mengetahui jumlah tepung daun lemna fermentasi dalam pakan yang berpengaruh terhadap pertumbuhan dan efisiensi pakan ikan gurami (Osphronemus gouramy). Penelitian ini menggunakan Rancangan Acak Lengkap (RAL) dengan satu faktor, lima taraf perlakuan dan tiga ulangan. Ikan yang digunakan berukuran bobot rata-rata $1,5 \mathrm{~g}$ dan panjang $4 \mathrm{~cm}$. Ikan dipelihara dalam keramba berukuran $1 \mathrm{~m}^{3}$ dengan padat tebar $25 \mathrm{ekor} / \mathrm{m}^{3}$. Perlakuan pada penelitian ini adalah pemberian pakan dengan penggantian tepung kedelai dengan tepung daun lemna fermentasi, adapun perlakuannya adalah kontrol P0 (0:100\%), P1 (10:90\%), P2 (15:85\%), P3 (20:80\%) dan P4 (25:75\%) untuk kandungan protein $30 \%$. Hasil penelitian menunjukkan bahwa tepung daun lemna fermentasi berpengaruh nyata $(\mathrm{P}<0,05)$ terhadap pertumbuhan, efisiensi pakan dan retensi protein. Hasil penelitian ini menunjukkan bahwa protein bungkil daun lemna yang difermentasi dapat menggantikan hingga 10\% dari tepung kedelai dalam pakan untuk pertumbuhan ikan gurami.
\end{abstract}

Kata Kunci: Ikan gurami, Lemna minor, Fermentasi, Pakan

\begin{abstract}
This research was conducted from December 2016 to February 2017. The aim of this study was to know the amount of fermented lemna leaf flour in the diet which affected the growth and feed efficiency of giant gouramy (Osphronemus gouramy). This study used a completely randomized design (CRD) with one factor, five treatment levels and three replications. The fish used have an average weight of $1.5 \mathrm{~g}$ and a length of $4 \mathrm{~cm}$. Fish were kept in cages measuring $1 \mathrm{~m}^{3}$ with a stocking density of $25 \mathrm{fish} / \mathrm{m}^{3}$. The treatment in this study was feeding by replacing soybean flour with fermented lemna leaf flour, while the treatments were control P0 (0:100\%), P1 (10:90\%), P2 (15:85\%), P3 (20:80\%) and P4 (25:75\%) for 30\% protein content. The results showed that fermented lemna leaf flour had a significant effect $(\mathrm{P}<0.05)$ on growth, feed efficiency and protein retention. The results of this study indicate that fermented lemna leaf meal protein can replace up to $10 \%$ of soybean meal in feed for growing gouramy.
\end{abstract}

Keyword: Giant gouramy, Lemna minor, Fermentation, Diet

\section{Pendahuluan}

Ikan gurami (Osphronemus gouramy) adalah spesies ikan air tawar yang mempunyai nilai ekonomis tinggi dan berpotensi cukup besar untuk dikembangkan sebagai ikan budidaya. Meningkatkan produksi budidaya ikan gurami yang secara alami pertumbuhan- nya lambat dapat dicapai dengan mempercepat pertumbuhan ikan yang dalam hal ini dibutuhkan pakan dengan kandungan nutrien yang sesuai dengan kebutuhan ikan tersebut.

Pakan merupakan salah satu faktor penting yang menentukan dalam keberhasilan usaha perikanan serta kebutuhan mutlak yang 
harus dipenuhi untuk kelangsungan hidup dan berbagai proses biologis di dalam tubuh ikan. Pengadaan pakan merupakan biaya terbesar dalam usaha perikanan bila dibandingkan dengan biaya produksi. Tingginya harga pakan dari pabrik disebabkan bahan baku utama pakan ikan seperti tepung ikan dan kedelai masih didatangkan dari luar negeri. Oleh karena itu harus dikembangkan formulasi pakan yang memiliki efisiensi pakan yang tinggi dengan biaya produksi pakan serendah mungkin, tetapi tidak mengurangi kandungan nutrien yang ada pada pakan.

Lemna (Lemna minor) adalah tanaman air kecil yang ditemukan tumbuh mengapung di atas air dengan tingkat penyebaran yang sangat luas di seluruh dunia dan potensial sebagai sumber hijauan pakan yang berkualitas tinggi bagi ternak. L. minor lebih dikenal sebagai gulma di perairan yang cenderung sulit untuk dikendalikan (Said, 2006), namun tanaman ini memiliki kandungan nutrisi yang tinggi. Selain itu, tanaman ini memiliki kemampuan fitoremediasi yang efektif dalam memperbaiki kualitas air yang tercemar limbah. L. minor efektif dalam memfiksasi nitrogen perairan yang tercemar limbah (Zimmo et al., 2005).

Kendala utama dalam pemanfaatan pakan hijauan sebagai bahan baku pakan ikan adalah tingginya kandungan serat kasarnya yang menyebabkan sulit dicerna dan dapat menurunkan kualitas dari pakan. Salah satu upaya yang dapat dilakukan untuk mengatasi tingginya kandungan serat kasar pada pakan hijauan adalah dengan melakukan proses fermentasi.

Fermentasi adalah satu cara untuk meningkatkan daya cerna bahan karena bahan yang difermentasi dapat mengubah substrat bahan tumbuhan yang susah dicerna menjadi protein sel tunggal dari organisme starter seperti Rhyzopus sp. dan Sacchromisess sp. dengan meningkatkan kadar protein bahan substrat (Boer dan Adelina, 2008). Berdasarkan latar belakang tersebut penulis tertarik untuk melakukan penelitian tentang pemanfaatan $L$. minor fermentasi dalam pakan buatan terhadap pertumbuhan benih ikan gurami (O. gouramy).

Tujuan penelitian ini untuk mengetahui persentase pemberian fermentasi tepung daun L.minor sebagai pengganti tepung kedelai dalam pakan buatan terhadap efisiensi pakan dan pertumbuhan ikan gurami.

\section{Metode Penelitian}

\subsection{Waktu dan Tempat}

Penelitian ini telah dilaksanakan pada bulan Desember 2016 sampai Februari 2017, penelitian ini dilakukan di kolam Balai Benih Sei Tibun Kampar, dan pembuatan pakan dilakukan di Labolatorium Nutrisi Ikan Fakultas Perikanan dan Kelautan Universitas Riau.

\subsection{Metode Penelitian}

Metode yang digunakan dalam penelitian adalah metode eksperimen dengan menggunakan Rancangan Acak Lengkap (RAL) satu faktor dengan 5 taraf perlakuan dan 3 kali ulangan sehingga diperlukan 15 unit percobaan. Perlakuan yang dilakukan dalam penelitian ini adalah sebagai berikut:

$\mathrm{P} 0=$ Tepung daun lemna fermentasi $0 \%$ : tepung kedelai $100 \%$

$\mathrm{P} 1=\mathrm{TLF} 10 \%$ : TK $90 \%$

$\mathrm{P} 2=$ TLF $15 \%:$ TK $85 \%$

$\mathrm{P} 3=$ TLF 20\%: TK 80\%

$\mathrm{P} 4=$ TLF $25 \%:$ TK $75 \%$

\subsection{Prosedur Penelitian}

\subsubsection{Persiapan Wadah dan Ikan Uji}

Wadah yang digunakan untuk pengamatan petumbuhan ikan dalam penelitian ini yaitu keramba berukuran $1 \times 1 \times 1$ $\mathrm{m}^{3}$ sebanyak 15 unit dengan padat tebar ikan sebanyak $25 \mathrm{ekor} / \mathrm{m}^{3}$. Wadah yang digunakan untuk mengukur kecernaan pakan, yaitu akuarium berukuran $60 \times 40 \times 40 \mathrm{~cm}^{3}$.

Ikan uji yang digunakan adalah benih ikan gurami berukuran $4 \mathrm{~cm}$ yang berasal dari salah seorang petani di daerah rumbio dengan bobot sekitar 1,5 g sebanyak 375 ekor untuk 15 wadah berupa karamba. Setiap wadah diisi benih gurami sebanyak $25 \mathrm{ekor} / \mathrm{m}^{3}$.

\subsubsection{Persiapan Tepung Lemna (L. minor)}

Tepung lemna ditambahkan air dengan perbandingan 1:1 (volume/berat), setelah itu diaduk sampai rata. Tepung lemna direbus lalu dikukus selama $1 \frac{1}{2}$ jam (dihitung sejak air kukusan mendidih). Tepung lemna yang telah direbus selama 15 menit lalu dikukus selama 30 menit, dibiarkan sampai dingin. Kemudian inokulasikan dengan inokulum Rhizopus 
oligosporus yang telah disiapkan dengan dosis $5 \%$ dari berat tepung. Tepung daun lemna yang telah dicampur dengan R.oligosporus kemudian dimasukkan ke dalam kantong plastik yang telah dilubangi dibeberapa bagian untuk mendapatkan kondisi aerob. Setelah proses fermentasi lemna berhasil, kemudian dijemur hingga kering dan dihaluskan menjadi tepung yang kemudian siap untuk diformulasikan ke dalam pakan. Kandungan protein dan serat kasar tepung daun lemna murni dan fermentasi dapat di lihat pada Tabel 1.

\subsubsection{Pembuatan Pelet}

Komposisi masing-masing bahan ditentukan sesuai dengan kebutuhan protein yang diharapkan, yaitu sebesar 30\%. Proporsi fermentasi L.minor ditentukan sesuai kebutuhan masing-masing perlakuan, sedangkan bahan-bahan lain disesuaikan jumlahnya berdasarkan hasil perhitungan. Bahan-bahan pakan yang digunakan ditimbang sesuai kebutuhan. Pencampuran bahan dilakukan secara bertahap, mulai dari jumlah yang paling sedikit hingga yang paling banyak agar campuran menjadi homogen. Selanjutnya bahan yang telah homogen ditambahkan air yang telah dimasak sebanyak 25-30\% dari bobot total bahan. Pelet dicetak pada penggilingan, kemudian dilakukan pengeringan dengan penjemuran. Pelet yang telah kering kemudian dianalisis proksimat. Hasil analisa proksimat disajikan pada Tabel 2 .

Tabel 1. Kandungan Protein dan Serat Kasar Tepung Lemna Murni dan Tepung Lemna Fermentasi

\begin{tabular}{ccc}
\hline Perlakuan & $\begin{array}{c}\text { Protein } \\
(\mathbf{\%})\end{array}$ & $\begin{array}{c}\text { Serat kasar } \\
(\mathbf{\%})\end{array}$ \\
\hline $\begin{array}{c}\text { Tepung lemna } \\
\text { murni }\end{array}$ & 29,11 & 14,20 \\
$\begin{array}{c}\text { Tepung lemna } \\
\text { fermentasi }\end{array}$ & 30,20 & 11,13 \\
\hline
\end{tabular}

Sumber: Analisa Disperindag kota Pekanbaru 2016

Tabel 2. Analisa Proksimat Pakan Uji pada Tiap Perlakuan

\begin{tabular}{lccccc}
\hline \multirow{2}{*}{$\begin{array}{c}\text { Komposisi } \\
\text { Proksimat (\%) }\end{array}$} & \multicolumn{5}{c}{ Perlakuan ( \% FTDL : \% TK ) } \\
\cline { 2 - 6 } & P0 (0 : 100) & P1 (10: 90) & P2 (15 : 85) & P3 (20 : 80) & P4 (25 : 75) \\
\hline Protein & 29,31 & 29,43 & 29,06 & 28,99 & 29,01 \\
Lemak & 4,31 & 4,24 & 5,02 & 4,67 & 6,32 \\
Air & 10,10 & 9,86 & 9,91 & 10,02 & 9,11 \\
Abu & 17,41 & 16,72 & 16,79 & 17,16 & 17,15 \\
Serat Kasar & 13,81 & 12,13 & 13,23 & 13,30 & 13,30 \\
BETN & 25,33 & 27,62 & 25,99 & 25,86 & 25,03 \\
\hline
\end{tabular}

\subsection{Parameter yang Diamati}

\subsubsection{Efisiensi Pakan}

Menurut Watanabe (1988) rumus menghitung efisiensi pakan adalah :

$$
\mathrm{EP}=\frac{(B t+B d)-B o}{F} \times 100 \%
$$

keterangan:

$$
\begin{aligned}
\mathrm{EP} & =\text { Efisiensi Pakan }(\%) \\
\mathrm{Bt} & =\begin{array}{l}
\text { Bobot biomassa ikan pada akhir } \\
\text { penelitian }(\mathrm{g})
\end{array} \\
\mathrm{Bo} & =\begin{array}{l}
\text { Bobot biomassa ikan pada awal } \\
\text { penelitian }(\mathrm{g})
\end{array} \\
\mathrm{Bd}= & \begin{array}{l}
\text { Bobot biomassa ikan yang mati } \\
\text { selama penelitian }(\mathrm{g})
\end{array} \\
\mathrm{F}= & \begin{array}{l}
\text { Jumlah pakan yang dikonsumsi } \\
\text { ikan selama penelitian }(\mathrm{g})
\end{array}
\end{aligned}
$$

\subsubsection{Laju Pertumbuhan Spesifik}

Menurut Huisman (1976) laju pertumbuhan spesifik diukur dengan menggunakan rumus:

\section{LPS $=($ LnWt-LnWo $) / t \times 100 \%$}

Keterangan :

LPS = Laju pertumbuhan spesifik (\%)

LnWt $=$ Bobot rata-rata ikan pada akhir penelitian $(\mathrm{g})$

LnWo = Bobot rata-rata ikan pada awal penelitian $(\mathrm{g})$

$\mathrm{t}=$ Lama penelitian (hari)

\subsubsection{Tingkat Kelulushidupan}

Menurut Effendie (2001), tingkat kelulushidupan dapat dihitung dengan rumus sebagai berikut:

$$
S R=\frac{N t}{N o} \times 100 \%
$$


Keterangan:

$\mathrm{SR}=$ Kelulushidupan (\%)

$\mathrm{Nt} \quad=$ Jumlah ikan yang hidup pada akhir penelitian (ekor)

No = Jumlah ikan yang hidup pada awal penelitian (ekor)

\subsubsection{Kualitas Air}

Parameter kualitas air yang diukur selama penelitian adalah suhu, $\mathrm{pH}$, dan oksigen terlarut (DO). Pengukuran ini dilakukan di awal, pertengahan dan akhir penelitian.

\subsection{Analisis Data}

Data yang diperoleh selama penelitian disajikan dalam bentuk tabel kemudian dihitung efisiensi pakan, laju pertumbuhan spesifik, dan kelulushidupan. Data dianalisa secara statistik dengan analisis ANOVA. Untuk mengetahui perbedaan antara tiap perlakuan, maka dilakukan uji lanjut yaitu uji Newman-Keuls. Sedangkan data kualitas air dianalisa secara deskriptif.

\section{Hasil dan Pembahasan}

\subsection{Kecernaan Pakan}

Data mengenai perhitungan kecernaan pakan ikan gurami (O. gouramy) pada setiap perlakuan selama penelitian dapat dilihat pada Tabel 3.

Tabel 3. Kecernaan Pakan (\%) Ikan gurami (O.gouramy)

\begin{tabular}{cc}
\hline $\begin{array}{c}\text { Perlakuan } \\
(\boldsymbol{\%} \text { FTDL }: \% \text { TK })\end{array}$ & $\begin{array}{c}\text { Kecernaan Pakan } \\
(\boldsymbol{\%})\end{array}$ \\
\hline P0 $(0: 100)$ & 67.74 \\
P1 $(10: 90)$ & 76.80 \\
P2 $(15: 85)$ & 70.15 \\
P3 $(20: 80)$ & 69.88 \\
P4 $(25: 85)$ & 69.70 \\
\hline Keterangan: *TK: Tepung kedelai, FTDL: \\
\multicolumn{2}{c}{ Fermentasi Tepung Daun Lemna }
\end{tabular}

Berdasarkan Tabel 3 menunjukkan bahwa nilai kecernaan pakan ikan berkisar antara 76.80-67.74\%. Nilai kecernaan pakan tertinggi terdapat pada perlakuan P1 (10\% FTDL) sebesar $76.80 \%$. Hal ini dikarenakan adanya proses fermentasi tepung daun lemna sehingga ikan dapat mencerna pakan dengan baik. Semakin tinggi nilai kecernaan pakan yang dikonsumsi oleh ikan, maka semakin tinggi pula nutrisi yang tersedia yang dapat diserap oleh ikan dan semakin sedikit nutrisi yang terbuang melalui feses sehingga ikan dapat memenuhi kebutuhannya untuk bertahan hidup, memperbaiki dan memperbaharui jaringan tubuh serta untuk pertumbuhan yang lebih baik.

Kecernaan pakan terendah pada perlakuan P0 memiliki tingkat kecernaan paling rendah yaitu $67.74 \%$ dibandingkan dengan perlakuan $\mathrm{P} 1, \mathrm{P} 2$ dan $\mathrm{P} 3$. Hal ini disebabkan rendahnya kemampuan ikan dalam mencerna pakan perlakuan P0 serta tingginya serat kasar yang terkandung di dalam pakan uji, yaitu $13.81 \%$ dibandingkan dengan perlakuan pakan uji lainnya. Kemampuan ikan mencerna pakan tergantung dari jenis dan jumlah serat kasar yang terdapat dalam pakan. Semakin tinggi kandungan serat yang terdapat dalam pakan ikan maka semakin lambat pertumbuhan dan kecernaannya.

\subsection{Efisiensi Pakan}

Data rata-rata efisiensi pakan ikan uji selama penelitian dapat dilihat pada Tabel 4.

Tabel 4. Efisiensi Pakan (\%) Ikan gurami (O. gouramy)

\begin{tabular}{cc}
\hline Perlakuan & Efisiensi Pakan $(\%)$ \\
\hline P0 $(0: 100)$ & $15.60 \pm 0.78^{\mathrm{a}}$ \\
P1 $(10: 90)$ & $21.07 \pm 0.77^{\mathrm{c}}$ \\
P2 $(15: 85)$ & $18.20 \pm 0.19^{\mathrm{b}}$ \\
P3 $(20: 80)$ & $18.81 \pm 0.42^{\mathrm{b}}$ \\
P4 $(25: 85)$ & $19.43 \pm 0.71^{\mathrm{b}}$ \\
\hline Keterangan : Huruf yang berbeda pada kolom \\
yang sama menunjukkan adanya \\
perbedaan yang nyata $(\mathrm{p}<0,05)$.
\end{tabular}

Tabel 4 menunjukkan nilai rata-rata efisiensi pakan ikan gurami sebesar 15.6021.07\%. Efisiensi pakan tertinggi terdapat pada perlakuan P1 (10\% fermentasi daun lemna), yaitu sebesar $21.07 \%$, sedangkan efisiensi pakan terendah terdapat pada perlakuan P0 (15.60\%). Hal ini disebabkan karena komposisi bahan pakan yang mengandung $10 \%$ fermentasi daun lemna dengan $90 \%$ tepung kedelai memiliki nilai kecernaan yang tinggi, yaitu $76,80 \%$ sehingga energi yang dikeluarkan untuk proses pencernaan lebih sedikit dan pakan lebih efisien dimanfaatkan ikan gurami. Nilai efisiensi pakan ditentukan oleh kemampuan ikan mencerna pakan yang diberikan. Sedangkan nilai efisiensi terendah pada perlakuan P0 yaitu, sebesar $15,60 \%$. Hal ini 
sejalan dengan kecernaan pakan yang terendah pada perlakuan P0 67,74\%. Boer dan Adelina (2008) menyatakan bahwa efisiensi pemanfaatan pakan yang di beri penambahan fermentasi lebih mudah dicerna dan diserap usus.

Nilai efisiensi pakan yang diperoleh selama penelitian ini sedikit lebih tinggi dibandingkan penelitian Haryadi et al. (2016) dengan menggunakan fermentasi eceng gondok pada pakan benih ikan gurami yang memperoleh nilai efisiensi pakan sebesar 14,96-21,01\%, namun lebih rendah dibandingkan dengan penelitian yang dilakukan Raudah et al. (2018) dengan menggunakan fermentasi daun lamtoro gung pada pakan benih ikan patin menghasilkan efisiensi pakan sebesar 40-62,2\%, 44,37-62,07\% pada ikan nila yang diberi pakan mengandung tepung azolla fermentasi (Husna et al., 2021). Sedangkan pada ikan baung yang diberikan pakan mengandung kayu apu fermentasi berkisar antara 41,76-46,47\% (Gunawan et al., 2021)

Hasil efisiensi pakan yang diperoleh selama penelitian ini sebesar 15,60-21,07\%, tergolong rendah. NRC (1993) menyatakan bahwa nilai efisiensi penggunaan pakan dalam kegiatan budidaya ikan yaitu 30-40\%.

\subsection{Retensi Protein}

Nilai retensi tertinggi pada perlakuan P1 (10\% fermentasi tepung lemna) yaitu sebesar $16.67 \%$. Nilai retensi protein P1 tinggi dikarenakan nilai kecernaan pakan dan efisiensi pakan yang tinggi juga, sedangkan rendahnya retensi pakan pada perlakuan P0 (tanpa daun lemna fermentasi) disebabkan karena kecernaan pakan dan efisiensi pakan yang rendah pada pakan ini. Hal ini sejalan dengan kecernaan pakan dan efisiensi pakan pada P1 yang tertinggi dan yang terendahnya pada retensi protein, P0 yaitu sebesar $11,77 \%$ (Tabel 5).

Nilai retensi protein dipengaruhi oleh kemampuan ikan untuk memanfaatkan protein secara optimal yang diperoleh dari protein pakan, apabila pakan yang diberikan dapat dimanfaatkan dengan baik maka efisiensi pakan tinggi dan akan tinggi juga nilai retensi protein ikan uji.

Boer dan Adelina (2008) menyatakan kemampuan ikan dalam memanfaatkan karbohidrat tergantung pada jenis dan kemampuan ikan dalam menghasilkan enzim amilase untuk mensitesa karbohidrat. Kemampuan enzim amilase dalam sistem pencernaan ikan untuk mencerna pakan umumnya terbatas. Selain protein dan karbohidrat, lemak merupakan komponen terpenting dalam pakan ikan (NRC, 1993).

Tabel 5. Retensi Protein (\%) ikan gurami (O. gouramy)

\begin{tabular}{cc}
\hline Perlakuan & Retensi Protein $(\%)$ \\
\hline P0 $(0: 100)$ & $11,77 \pm 0,49^{\mathrm{a}}$ \\
P1 $(10: 90)$ & $16,67 \pm 0,55^{\mathrm{c}}$ \\
P2 $(15: 85)$ & $13,82 \pm 0,14^{\mathrm{b}}$ \\
P3 $(20: 80)$ & $14,61 \pm 0,30^{\mathrm{b}}$ \\
P4 $(25: 85)$ & $14,35 \pm 0,47^{\mathrm{b}}$ \\
\hline Keterangan : Huruf yang berbeda pada baris \\
yang sama menunjukkan adanya \\
perbedaan yang nyata $(\mathrm{p}<0,05)$.
\end{tabular}

\subsection{Laju Pertumbuhan Spesifik}

Hasil pengamatan terhadap pertumbuhan ikan gurami yang diperoleh selama 56 hari dapat dilihat bahwa adanya peningkatan pertumbuhan ikan gurami selama penelitian walaupun pada 14 hari pertama pertumbuhan ikan pada setiap perlakuan masih relatif sama. Hal tersebut disebabkan karena ikan gurami dapat memanfaatkan pakan sehingga berpengaruh terhadap peningkatan bobot tubuhnya pada setiap perlakuan. Pemberian pakan yang mengandung $10 \%$ fermentasi tepung Lemna (P1) menghasilkan bobot rata-rata individu tertinggi, yaitu $4.83 \mathrm{~g}$. Keadaan tersebut mengartikan bahwa pakan dengan bahan fermentasi tepung lemna $10 \%$ dapat diterima oleh ikan dengan baik untuk meningkatkan bobot tubuh ikan (Gambar 1).

Pertumbuhan ikan pada setiap sampling mengalami kenaikan disebabkan oleh faktor internal dan eksternal. Menurut Agustono et al. (2014) adapun faktor internal diantaranya adalah keturunan, jenis kelamin, umur, parasit dan penyakit, sedangkan yang termasuk faktor luar adalah pakan dan kualitas perairan di sekitar wadah pemeliharaan. Hal tersebut dapat membuktikan bahwa pakan dapat dimanfaatkan dengan baik oleh ikan sehingga menghasilkan pertumbuhan ikan yang baik.

Rata-rata laju pertumbuhan spesifik ikan gurami yang dipelihara selama penelitian berkisar 1,39-1,78\%. Rata-rata laju pertumbuhan spesifik tertinggi terdapat pada P1 sebesar $1.78 \%$ dan yang terendah terdapat pada perlakuan P0 yaitu $1.39 \%$. Berdasarkan analisa variansi (ANAVA) penggunaan 
fermentasi tepung lemna yang digunakan dalam pakan berpengaruh nyata $(\mathrm{P}<0,05)$ terhadap laju pertumbuhan spesifik. Hasil uji lanjut student Newman Keuls menunjukkan perlakuan P1 $(5,33 \%)$ berbeda nyata terhadap perlakuan P0 (4,17\%) P2 (4,68\%), P3 (4,77\%) dan P4 (4,84\%). (Tabel 6).

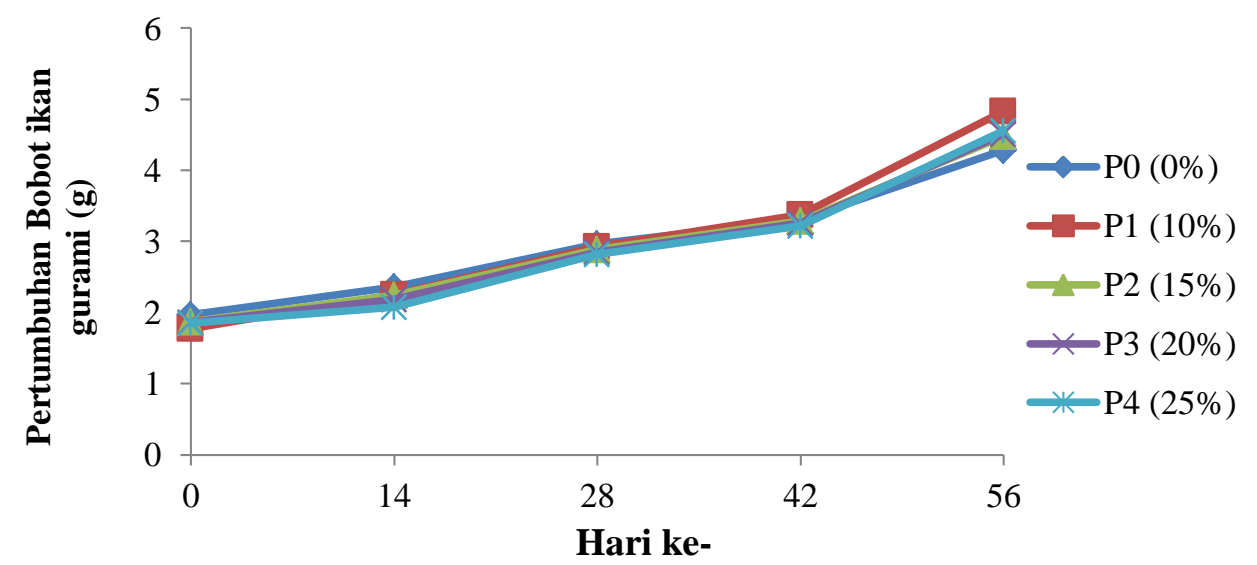

Gambar 1. Laju pertumbuhan ikan gurami selama penelitian

Tabel 6. Laju Pertumbuhan Spesifik Ikan Gurami (O.gouramy)

\begin{tabular}{cc}
\hline Perlakuan & Efisiensi Pakan $(\%)$ \\
\hline P0 $(0: 100)$ & $1,39 \pm 0,91^{\mathrm{a}}$ \\
P1 $(10: 90)$ & $1,78 \pm 0,49^{\mathrm{c}}$ \\
P2 $(15: 85)$ & $1,56 \pm 0,00^{\mathrm{b}}$ \\
P3 $(20: 80)$ & $1,59 \pm 0,20^{\mathrm{b}}$ \\
P4 $(25: 85)$ & $1,61 \pm 0,52^{\mathrm{b}}$ \\
\hline Keterangan : Huruf yang berbeda pada kolom \\
yang sama menunjukkan adanya \\
perbedaan yang nyata $(\mathrm{p}<0,05)$.
\end{tabular}

Berdasarkan dari data pada Tabel 6 diketahui bahwa pemberian fermentasi tepung lemna $10 \%$ dan $90 \%$ tepung kedelai ke dalam pakan menghasilkan pertumbuhan ikan lebih baik karena pada perlakuan tersebut ikan mampu memanfaatkan pakan dengan lebih baik untuk pertumbuhannya. Protein merupakan nutrien yang paling berpengaruh untuk dapat memacu pertumbuhan ikan. Pada penelitian ini pakan pada P1 (10\% fermentasi tepung lemna) menghasilkan pertumbuhan ikan lebih cepat, karena apabila pakan yang diberikan mempunyai nilai nutrisi yang baik, maka dapat mempercepat laju pertumbuhan. Zat-zat nutrisi yang dibutuhkan adalah protein, lemak, karbohidrat, vitamin dan mineral (Handajani dan Widodo, 2010).

Hasil penelitian Danu (2015) pemanfaatan fermentasi tepung daun singkong $10 \%$ pada pakan benih ikan gurami menghasilkan laju pertumbuhan spesifik 2,24 $\%$, selanjutnya penelitian Kurniawan et al. (2019) menyatakan pemberian fermentasi tepung daun kelor sebanyak $15 \%$ pada pakan benih ikan gurami menghasilkan laju pertumbuhan spesifik $1,58 \%$. Nilai laju pertumbuhan spesifik tertinggi pada penelitian ini adalah $1,78 \%$.

\subsection{Tingkat Kelulushidupan}

Kelulushidupan ikan gurami dapat diperoleh dari pengamatan setiap hari dimana semakin berkurangnya ikan uji pada perlakuan selama penelitian dan diperoleh melalui perhitungan yang dinyatakan dalam persen. Angka kelulushidupan benih ikan gurami yang diperoleh selama penelitian berkisar antara $100 \%$. Kelulushidupan ikan dapat dipengaruhi oleh kualitas air, dan nutrisi pakan yang diberikan. Adapun data hasil perhitungan kelulushidupan ikan gurami dapat dilihat pada Gambar 2.

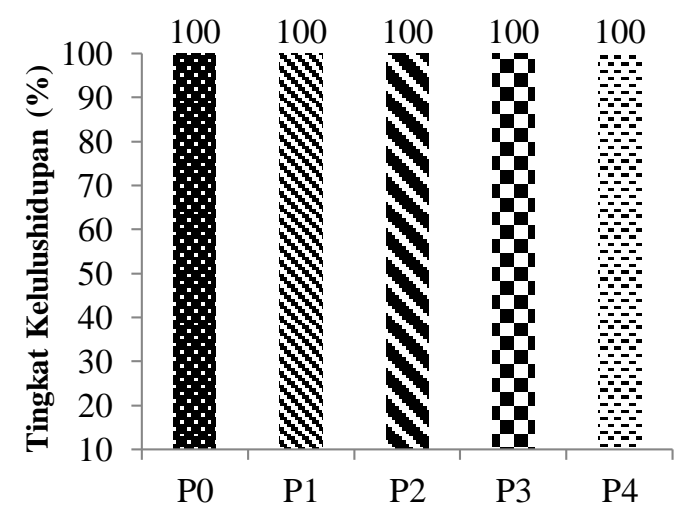

Gambar 2. Tingkat Kelulushidupan Ikan Gurami 
Menurut Armiah (2010) faktor yang mempengaruhi tinggi rendahnya kelangsungan hidup adalah faktor biotik antara lain kompetitor, kepadatan, populasi, umur dan kemampuan organisme beradaptasi terhadap lingkungan. Namun angka kelulushidupan pada penelitian ini tidak mengartikan bahwa pakan disukai oleh ikan karena dilihat dari pertumbuhan ikan yang baik

\subsection{Kualitas Air}

Data kualitas air yang diperoleh selama penelitian termasuk baik bagi kehidupan ikan gurami karena angka tersebut memenuhi nilai standar pengukuran kualitas air. Cahyono (2000) menyatakan faktor eksternal yang mempengaruhi pertumbuhan dan sintasan ikan uji adalah air sebagai media hidup. Pada penelitian ini kualitas air yang diukur adalah suhu, derajat keasaman $(\mathrm{pH})$ dan oksigen terlarut (DO). Data hasil pengukuran kualitas air dapat dilihat pada Tabel 7.

Tabel 7. Data Hasil Pengukuran Kualitas Air

\begin{tabular}{|c|c|c|c|c|}
\hline \multirow{2}{*}{ Parameter } & \multicolumn{3}{|c|}{ Kisaran } & \multirow{2}{*}{$\begin{array}{l}\text { Nilai Standar } \\
\text { Pengukuran * }\end{array}$} \\
\hline & Awal & Pertengahan & Akhir & \\
\hline Suhu $\left({ }^{0} \mathrm{C}\right)$ & $27-28$ & $26-29$ & $27-30$ & $25-30$ \\
\hline pH & $5-6$ & $5-6$ & $5-6,5$ & $6,5-8,5$ \\
\hline DO (ppm) & $4,0-4,4$ & $3,0-4,7$ & $4,3-5$ & $\geq 4$ \\
\hline $\mathrm{NH}_{3}(\mathrm{ppm})$ & 0,0028 & 0,0018 & 0,0011 & $<1$ \\
\hline
\end{tabular}

Keterangan :*Kordi (2010)

Suhu yang didapat selama penelitian berkisar antara $26-31^{\circ} \mathrm{C}$. Menurut Cahyono (2000) nilai kualitas air yang baik yaitu $\mathrm{pH}$ berkisar 7,5 - 8,5 mg/L, oksigen terlarut (DO) 5-7 mg/L, kadar amoniak 0,1 ppm dan kandungan fosfat yang baik untuk pertumbuhan ikan adalah maksimal $1 \mathrm{mg} / \mathrm{L}$. Selain itu hasil pengamatan tentang data kualitas air yang diperoleh juga didukung oleh pendapat Boyd (1979) kisaran pH yang baik untuk kehidupan ikan berkisar antara 5,4-8,6 dan kandungan oksigen terlarut yang baik adalah 5-7 ppm

\section{Kesimpulan dan Saran}

Kesimpulan dari penelitian ini adalah persentase pemberian fermentasi tepung daun L.minor sebagai pengganti tepung kedelai dalam pakan buatan, yaitu dengan perlakuan yang terbaik penambahan fermentasi tepung lemna sebanyak $10 \%$ kedalam pakan dimana pertumbuhannya paling baik dan menghasilkan rata-rata kecernaan pakan $67,74 \%$, efisiensi pakan sebesar $21,07 \%$, retensi protein $16.67 \%$, dan laju pertumbuhan spesifik $1.78 \%$ /hari.

Penulis menyarankan untuk menggunakan bahan baku daun lemna difermentasi dalam pakan ikan herbivora. Penulis juga menyarankan agar dalam proses fermentasi digunakan fermentor jenis yang lain, seperti Sacchromyces sp. agar dapat diketahui hasil dari proses fermentasi yang lebih baik.

\section{Daftar Pustaka}

Afrianto dan Liviwaty. (2005). Penggunaan Microflora Saluran Pencernaan sebagai Probiotik untuk Meningkatkan Pertumbuhan dan Kelangsungan Hidup Ikan Bandeng. Disertasi. Sekolah Pascasarjana. Institut Pertanian Bogor. Bogor. $68 \mathrm{hlm}$

Agustono, E. Centyana, dan Y. Cahyoko. (2014). Substitusi Tepung Kedelai dengan Tepung Biji Koro Pedang (Canavalia ensiformis) terhadap Pertumbuhan, Survival Rate dan Efisiensi Pakan Ikan Nila Merah. Jurnal Ilmiah Perikanan dan Kelautan (1):6.14

Armiah, J. (2010). Pemanfaatan Fermentasi Ampas Tahu dalam Pakan terhadap Pertumbuhan Benih Ikan Selais (Ompok hypophthalmus). Skripsi. Fakultas Perikanan dan Ilmu Kelautan Universitas Riau. Pekanbaru.

Boer, I dan Adelina. (2008). Ilmu Nutrisi dan Pakan Ikan. Fakultas Perikanan dan Ilmu Kelautan Universitas Riau. Pekanbaru. $78 \mathrm{hlm}$

Boyd, C.E. (1979). Water Quality in Warmwater Fish Pond. Auburn University. Aqricultural Experiment Station, Auburn. 359 p. 
Cahyono, B. (2000). Budidaya Ikan Air Tawar. Ikan Gurami, Nila, Mas. Penerbit Kanasius. Yogyakarta. 113 hlm.

Effendie, M.I. (2002). Metodologi Biologi Perikanan. Yayasan Pustaka Nusantara. Yogyakarta. $163 \mathrm{hlm}$.

Gunawan, G., Adelina, dan I. Suharman. (2021). Utilization of Fermented Pistia stratiotes L. Flour in Diet for Growth Asian Redtail Catfish (Hemibagrus nemurus). Jurnal Ilmu Perairan (Aquatic Science), 9(1): 23-30

Handajani. H., dan W. Widodo. (2010). Nutrisi Ikan. PT. Raja Grafindo Persada malang. $37 \mathrm{hlm}$.

Haryadi, P., I. Suharman, dan Adelina. (2016). Effect of Water Hyacinth (Eichhornia Crassipes) Fermentation using a Cow Rumen Fluid as Fish Meal of Osphronemus gourami Fingerling. JOM Faperika. Unri

Huisman, E.A. (1976). Food Conversion Efficiencies at Maintained and Production Level Carp Cyprinus carpio L. and Rainbow trout Salmo gairdneri. Aquaculture.

Husna, R., I. Suharman, dan Adelina. (2021). Utilization of Azzola Flour (Azzola microphylla Fermentation in Diet to Increase Growth of Red Tilapia (Oreochromis niloticus). Jurnal Ilmu Perairan (Aquatic Science), 9(1): 6-15

Kordi, G.H. (2010). Budidaya Ikan gurame di Kolam Terpal. Lily Publisher. $22 \mathrm{hlm}$.

Kurniawan, D., I. Suharman, dan Adelina. (2019). The Effect of Fermented Moringa oliefera Leaf Meal in The
Formualted Diets of Gouramy (Osphronemus gouramy). Jurnal Perikanan dan Kelautan, 24(1): 1-9

NRC. (1993). Nutritional Requirement of Warmwater Fishes. National Academic of Science. Washington, D. C. 248 p.

Raudah, P., I. Suharman, dan H. Alawi. (2018). Utilization of Leucaena Leaves Meal Gung (Leucaena leucocephala) Fermented by Aspergillus niger as Subtitution of Soybean Meal in the Diets on the Growth of Thai Cat Fish (Pangasius hypophthalmus). Jurnal Perikanan dan Kelautan, 23(2): 1-8

Said A. (2006). Pengaruh komposisi Hydrilla verticillata dan Lemna minor sebagai Pakan Harian terhadap Pertumbuhan dan Sintasan Ikan Nila Merah (Oreochromis niloticus x Oreochromis mossambicus) dalam Keramba Jaring Apung di Perairan Umum Das Musi. Prosiding Seminar Nasional Ikan IV Jatiluhur.

Watanabe, T. (1988). Fish Nutrition And Marine Culture. Departement of Aquatic Biosciencis Fisheries. Tokyo University of Jica. 233 pp.

Zimmo, O.R., N.P. Van der Steen, dan H.J. Gijzen. (2005). Effect of Organic Surface Load on Process Performance of Pilot Scale Algae and DuckweedBased Waste Stabilization Ponds. J. Environ Eng, 131:587-594.

Zonneveld, N., E.A. Huisman, dan J.H. Boon. (1991). Prinsip-prinsip Budidaya Ikan Diterjemahkan oleh Tirtajaya. Gramedia Pustaka Utama. Jakarta. 318 hlm 